\title{
CagA/cytotoxic strains of Helicobacter pylori and interleukin-8 in gastric epithelial cell lines
}

\author{
J E Crabtree, S M Farmery, I J D Lindley, N Figura, P Peichl, D S Tompkins
}

\begin{abstract}
Aims-To investigate: (1) whether Helicobacter pylori directly induces interleukin-8 (IL-8) message expression and protein secretion in established gastric epithelial cell lines; and (2) if CagA/cytotoxin positive and negative strains of $H$ pylori differ in their ability to induce epithelial IL-8.
\end{abstract}

Methods-Gastric epithelial cell lines were co-cultured with $H$ pylori NCTC 11637 and 10 clinical isolates (four cytotoxic, six non-cytotoxic) and secreted IL-8 was measured by enzyme linked immunosorbent assay (ELISA). Specific induction of gastric epithelial IL-8 mRNA was examined by reverse transcription and polymerase chain reaction (RTPCR) amplification.

Results-H pylori (NCTC 11637) induced IL-8 secretion from three gastric epithelial cell lines (KATO-3, ST42, AGS) but not from MKN 45 (gastric) or intestinal (SW480, HT29) cell lines. $H$ mustelae did not stimulate IL-8 secretion from KATO3, ST42, and AGS cells. $H$ pylori induced IL-8 secretion was reduced by heat killing, sonication, freeze thawing or formalin fixation of the bacteria. CagA/cytotoxin positive strains of $H$ pylori induced significantly higher IL-8 secretion than CagA/cytotoxin negative strains in the three positive gastric epithelial cell lines (KATO-3, ST42: p < 0.01; AGS: p < $0.02)$. A significant increase $(p<0.01)$ in the expression of IL-8 $\mathrm{mRNA}$ relative to G3PDH mRNA was observed in KATO-3 cells after three hours of co-culture with CagA/cytotoxin positive strains.

Conclusions-H pylori directly increases gastric epithelial IL-8 mRNA expression and IL-8 protein secretion in a strain specific manner. Induction of epithelial IL-8 by CagA/cytotoxin positive strains is likely to result in neutrophil chemotaxis and activation and thus mucosal damage. These observations on epithelial IL-8 may explain the association between CagA/cytotoxin positive strains and gastroduodenal disease.

(F Clin Pathol 1994;47:945-950)

Helicobacter pylori infection is strongly associated with polymorphonuclear cell infiltration into the gastric mucosa. ${ }^{1}$ This cellular response probably represents a primary immune defence mechanism against a micro- bial pathogen. However, infection with $H$ pylori is chronic, and while neutrophils can effectively phagocytose $H$ pylor in vitro, ${ }^{2}$ there is little evidence that host defence mechanisms eradicate infection in vivo. Once activated, neutrophils have considerable potential for releasing proteolytic enzymes which may damage mucosal integrity. ${ }^{3}$

$H$ pylori produces various factors which will attract or activate neutrophils in vitro. ${ }^{24-7}$ Infection with $H$ pylori, however, also results in increased gastric mucosal production of interleukin-8 (IL-8), ${ }^{8}$ a cytokine which is a potent activator and chemotactic agent for neutrophils..$^{9-11}$ IL-8 has recently been implicated in the pathogenesis of several inflammatory or infectious conditions. ${ }^{12-16}$ In gastritis the in vitro mucosal production of IL-8 is substantially increased in active gastritis where polymorphs infiltrate into the epithelial layer. ${ }^{8}$ As gastric epithelial cells express IL-8, ${ }^{17}$ they may have an important role in regulating primary host defence mechanisms and be functionally involved in the neutrophilic response to $H$ pylori infection. In common with other epithelial cells, gastric epithelial production of IL-8 is regulated by cytokines. ${ }^{18}$ Bacterial factors may also be important. Studies of urinary epithelial cell lines have recently shown that adherent Escherichia coli will induce IL-8 secretion. ${ }^{19}$

Recent studies have shown that a mucosal IgA response to the 120 kilodalton protein of $H$ pylori is strongly associated with polymorph infiltration into the gastric epithelium. ${ }^{20}$ This high molecular weight protein, which is strongly associated with bacterial cytotoxicity, ${ }^{21-23}$ has recently been termed the CagA protein following cloning of the gene. ${ }^{24} 25$ The CagA gene is nearly always absent from noncytotoxic strains, ${ }^{24}{ }^{25}$ so mucosal IgA recognition of the gene product is likely to reflect the characteristics of the colonising strain(s). The linking of the mucosal IgA response to the CagA protein and polymorph infiltration could reflect differences in induction of IL-8.

In this study we investigated whether $H$ pylori directly induces IL-8 secretion from gastric epithelial cell lines and examined whether cytotoxic strains expressing the CagA protein differed from $\mathrm{CagA} /$ cytotoxin negative strains in their ability to induce epithelial IL-8 mRNA expression and IL-8 protein secretion.

\section{Methods}

GASTROINTESTINAL EPITHELIAL CELL LINES

Four gastric epithelial cell lines KATO-3 (European Collection of Animal Cell Cultures 
(ECACC), Salisbury, Wiltshire), AGS (ECACC), MKN $45^{26}$ and ST42 $2^{27}$ (kindly provided by $\mathrm{Dr} S$ Watson) were used. Intestinal cell lines HT29 (ECACC) and SW480 (ECACC) were used as controls. Cell lines were routinely maintained in RPMI 1640 (ICN-Flow Laboratories, High Wycombe, Bucks) supplemented with $10 \%$ heat inactivated fetal calf serum (FCS) (Sera Lab, Crawley, Surrey) and $40 \mu \mathrm{g} / \mathrm{ml}$ gentamicin. Initial studies had shown that all six lines secreted IL-8 in response to IL- $1 \beta$ (gift of Glaxo Group Research, UK). The intestinal cell lines HT29 28 and SW480 were selected as controls because they secreted high IL-8 concentrations in response to cytokines (HT29, SW480) and adherent $E$ coli (SW480) (unpublished observations).

\section{BACTERIA}

The type strain of $H$ pylori NCTC 11637 (CagA/cytotoxin positive) and 10 clinical isolates were used. Six strains (G12, G17, G21, $\mathrm{G} 25, \mathrm{G} 47, \mathrm{G} 50$ ) were non-cytotoxic and four strains (G27, G32, G39, G65) were cytotoxic. Western blotting of whole cell bacterial preparations with CagA antibody positive human sera showed that the cytotoxic strains all expressed the high molecular weight CagA protein and that this protein was not expressed in the non-cytotoxic strains. Two strains of $H$ mustelae (NCTC 12031 and NCTC 12032, both CagA/cytotoxin negative) were used as controls. Bacteria were grown on blood agar base Number 2 (Oxoid, Basingstoke, Hants) incorporating 7\% fresh horse blood and harvested on day 4 into phosphate buffered saline (PBS) and used immediately.

In some experiments $H$ pylori NCTC 11637 were heat killed ( 30 minutes, at $80^{\circ} \mathrm{C}$ ), sonicated, freeze-thawed or fixed in $0.5 \%$ formalin (30 minutes). Formalin fixed bacteria were washed three times in PBS and resuspended in culture medium. Ultracentrifuged (100 $000 \times g$ for one hour) supernatant fluids of sonicated NCTC 11637 were also used at a concentration of $10 \mu \mathrm{g} / \mathrm{ml}$.

\section{BACTERIAL-EPITHELIAL CO-CULTURE EXPERIMENTS}

Epithelial cells were plated into 24 well plates (ICN-Flow) at a density of $1 \times 10^{5} / \mathrm{ml}$ and cultured for three days to confluence (about $5 \times 10^{5} / \mathrm{ml}$ ). Bacteria were washed in RPMI 1640 containing $10 \%$ FCS without gentamicin and resuspended at a concentration of $2 \cdot 5 \times 10^{7} / \mathrm{ml}$. Epithelial cells were cultured alone or with bacterial preparations for 24 hours at $37^{\circ} \mathrm{C}$ in a $95 \%$ air and $5 \% \quad \mathrm{CO}_{2}$ humidified incubator. At the end of culture supernatant fluids were aspirated and frozen at $-70^{\circ} \mathrm{C}$ until assayed and cell viability determined by trypan blue exclusion. No differences in epithelial cell viability in experimental and control cultures without $H$ pylori were evident.

The carboxylic ionophore monensin (Sigma, Poole, Dorset), which has been shown to block cytoplasmic vacuolisation induced by $H$ pylori cytotoxin, ${ }^{29}$ was included in some experiments at concentrations of $2-10 \mu \mathrm{g} / \mathrm{ml}$. The effect of monensin on $H$ pylori induced IL-8 secretion was compared with IL- $1 \beta$ induced IL- 8 secretion.

IL-8 ELISA

IL-8 concentrations in culture supernatant fluids were assayed by enzyme linked immunosorbent assay (ELISA) as described before ${ }^{8}$ using a murine monoclonal antibody to IL-8 and a phosphatase conjugated goat anti-IL8 polyclonal antibody. Culture supernatant fluids were diluted 1 in 4 in PBS/ $0 \cdot 1 \%$ Tween containing $1 \%$ bovine serum albumin (BSA). Concentrations of IL-8 were determined from a standard curve $(62.5 \mathrm{pg} / \mathrm{ml}-$ $2000 \mathrm{pg} / \mathrm{ml}$ ) of recombinant IL-8 (Sandoz, Vienna, Austria). Bacterial induced IL-8 secretion was expressed as $\mathrm{ng} / \mathrm{ml}$ following subtraction of background unstimulated control culture values.

\section{IL-8-mRNA}

The effects of CagA/cytotoxin positive and CagA/cytotoxin negative $H$ pylori on epithelial IL-8 mRNA expression in KATO-3 cells were examined. After three hours of bacterial coculture, total RNA from KATO-3 cells was extracted using RNAzolB (Biogenesis Ltd, Bournemouth). Briefly, cells were pelleted and resuspended in $1 \mathrm{ml} \mathrm{RNAzolB}$ with $0 \cdot 1$ $\mathrm{ml}$ chloroform, the phases separated, and RNA precipitated from the aqueous phase with an equal volume of isopropanol. The ethanol washed pellets were then resuspended in $20 \mu \mathrm{l}$ water containing RNase inhibitor. Messenger RNA was reverse transcribed using MMLV-RT primed with oligo dT15. The cDNA was PCR amplified for 20 cycles with primers specific for IL- $8^{17}$ and an internal control gene glyceraldehyde 3-phosphate dehydrogenase (G3PDH). To determine the ratio of IL-8 mRNA to G3PDH mRNA, ${ }^{33}$ P-dATP (Amersham, Bucks, UK) was added to the PCR reaction and the ratio of incorporation of radiolabel into IL-8 and G3PDH PCR products quantified by scintillation counting. Results are expressed as a mean of five determinations.

Data are expressed as mean (SEM). Differences in IL-8 secretion and IL-8 mRNA expression following co-culture with cytotoxic and non-cytotoxic strains were examined using the Mann-Whitney U test.

\section{Results}

No detectable IL-8 was secreted by unstimulated MKN 45, HT29, or SW480 cell lines over 24 hours. In the KATO-3, ST42, and AGS cell lines 24 hour IL-8 secretion from unstimulated cells ranged from $0-2 \cdot 38$, $0-1 \cdot 38$, and $0-0 \cdot 24 \mathrm{ng} / \mathrm{ml}$, respectively. The 24 hour secretion of IL -8 from all six cell lines following co-culture with the $H$ pylori type strain NCTC 11637 is shown in table 1 . AGS, KATO-3, and ST42 cells all secreted IL-8 on co-culture with $H$ pylori but bacterial co-culture induced minimal or no IL-8 
Table 1 Mean (SEM) IL-8 secretion by gastrointestinal cell lines after 24 hour culture with $H$ pylori strain NCTC 11637 or H mustelae strain NCTC 12032

\begin{tabular}{lll}
\hline & \multicolumn{1}{l}{$I L-8$ secretion $(\mathrm{ng} / \mathrm{ml})$} \\
\cline { 2 - 3 } Cell line & H pylori & H mustelae \\
\hline KATO-3 & $5 \cdot 1(0 \cdot 53)$ & 0 \\
ST42 & $2 \cdot 8(0 \cdot 81)$ & 0 \\
AGS & $3 \cdot 9(0 \cdot 14)$ & 0 \\
MKN45 & 0 & ND \\
HT29 & 0 & ND \\
SW480 & $0 \cdot 24(0 \cdot 13)$ & ND
\end{tabular}

$\mathrm{ND}=$ not done $\mathrm{n}=5$.

Table 2 Effects of heat killing, freeze-thawing, sonication and formalin fixation on $H$ pylori (NCTC 11637) induced IL-8 secretion by ST42 gastric epithelial cells

\begin{tabular}{lll}
\hline & NCTC 11637 & (Mean SEM) IL-8 secretion $(\mathrm{ng} / \mathrm{ml})$ \\
\hline (A) & Heat killed & $0.86(0.08)^{\star}$ \\
& Freeze-thawed & $0.81(0.08)^{\star}$ \\
& Sonicated & $0.74(0.17)^{\star}$ \\
& No treatment & \\
(matched controls) & $2.5(0.44)$ \\
(B) & Formalin fixed & $0.66(0.03)^{\star}$ \\
& No treatment & \\
(matched controls) & $3.59(0.27)$ \\
\hline
\end{tabular}

$\star p<0.02$ from untreated controls; $n=5$.

Figures $1 A-C \quad I L-8$ secretion (net) from KATO-3 $(A)$, ST42 (B), and $A G S$ (C) gastric epithelial cells after 24 hours of co-culture with CagAlcytotoxin positive and CagA/cytotoxin negative strains of $H$ pylori. Values are mean (SEM) $(n=5)$.
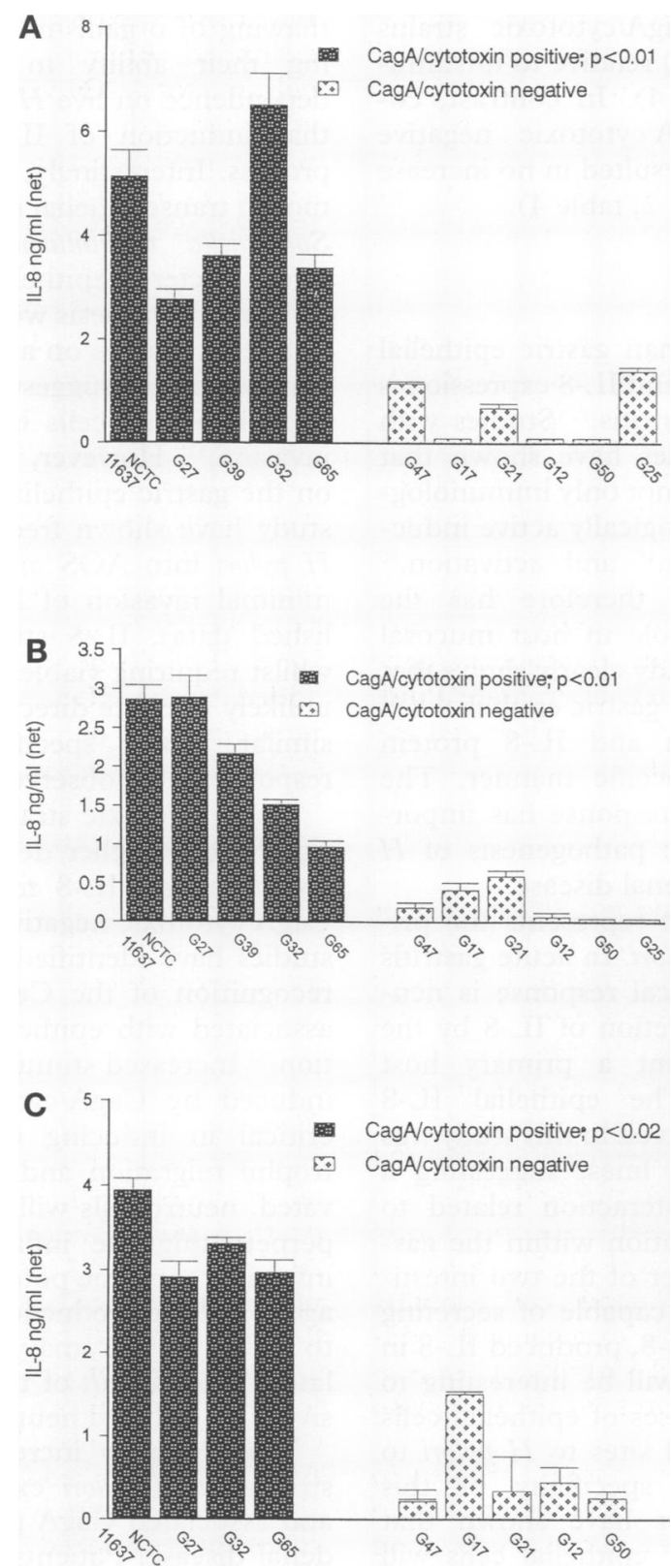

secretion from MKN 45 gastric cells or HT29 and SW480 intestinal cells. Neither of the two strains of $H$ mustelae induced IL-8 secretion from the three human gastrointestinal epithelial cell lines producing IL-8 in response to $H$ pylori (table 1).

The effects of heat killing, sonication, and freeze-thawing of $H$ pylori on bacterial induced IL-8 secretion from the ST42 epithelial cell line are shown in table 2 . A significant reduction $(p<0.02)$ in IL-8 secretion was apparent if non-viable bacterial preparations were used. Formalin fixation of $H$ pylori also significantly reduced $(p<0.02) 24$ hour IL-8 secretion by ST42 cells compared with unfixed paired control cultures of $H$ pylori (table 2). No secretion of IL-8 was observed in the three cell lines after co-culture with ultracentrifuged supernatant fluids at a concentration of $10 \mu \mathrm{g} / \mathrm{ml}$.

IL-8 production from KATO-3, ST42, and AGS gastric epithelial cell lines after 24 hours of co-culture with CagA/cytotoxin positive and negative strains of $H$ pylori is shown in figs 1A-C. In all three cell lines the CagA/cytotoxin positive strains induced significantly higher IL-8 secretion than the CagA/cytotoxin negative strains (KATO-3, ST42: $\mathrm{p}<0.01$; AGS: $\mathrm{p}<0.02$ )

The effects of monensin on $H$ pylori (NCTC 11637) and IL-1 $\beta$ induced IL-8 secretion by ST42 cells are shown in table 3 . No reduction in epithelial cell viability or stimulation of IL-8 secretion was observed in controls cultured with monensin alone. Monensin at 2, 5, and $10 \mu \mathrm{g} / \mathrm{ml}$ significantly reduced the 24 hour IL-8 production induced by $H$ pylori $(\mathrm{p}<0.02,10 \mu \mathrm{g} / \mathrm{ml} ; \mathrm{p}<0.05,5$ $\mu \mathrm{g} / \mathrm{ml} ; \mathrm{p}<0.02,2 \mu \mathrm{g} / \mathrm{ml}$ ) (table 3). A significant reduction $(\mathrm{p}<0.01)$ in IL-1 $\beta(10 \mathrm{ng} / \mathrm{ml})$ induced IL-8 production by ST42 cells was also observed on co-culture with monensin. Monensin similarly inhibited both $H$ pylori and IL- $1 \beta$ induced IL-8 secretion in the AGS and KATO-3 cell lines (data not shown).

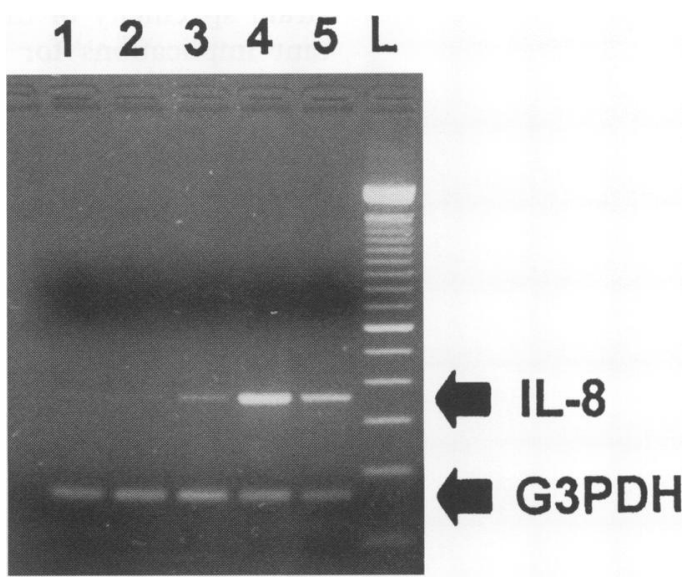

Figure $2 \quad P C R$ analysis of $m R N A$ using primers specific for IL-8 (369 base pairs) and G3PDH (157 base pairs) in KATO-3 gastric epithelial cells after three hours of coculture with $H$ pylori. Cell only control (lane 1), CagAl cytotoxin negative strains G25 and G50 (lanes 2 and 3), CagA/cytotoxin positive strains G32 and NCTC 11637 (lanes 4 and 5), 100 base pair ladder (Gibco-BRL) (lane L). 
Table 3 Effects of monensin on H pylori (NCTC 11637) and IL-1 induced IL-8 secretion from ST42 gastric epithelial cells

\begin{tabular}{|c|c|c|c|c|c|}
\hline \multicolumn{4}{|c|}{ H pylori (NCTC 11637) } & \multicolumn{2}{|c|}{$I L-1 \beta(10 \mathrm{ng} / \mathrm{ml})$} \\
\hline $\begin{array}{l}\text { Monesin } \mu \mathrm{g} / \mathrm{ml} \\
\text { IL-8 } \mathrm{ng} / \mathrm{ml}\end{array}$ & $\begin{array}{l}2 \\
2.09(0.08)^{\star \star}\end{array}$ & $\begin{array}{l}5 \\
2.45(0.22)^{\star}\end{array}$ & $\begin{array}{l}10 \\
2 \cdot 32(0 \cdot 13)^{\star \star}\end{array}$ & $\begin{array}{l}0 \\
6.25(0.46)\end{array}$ & ${ }_{3.29}^{10}(0 \cdot 27)^{\star \star}$ \\
\hline
\end{tabular}

Values are mean (SEM), $n=5$.

Mann-Whitney U test: ${ }^{\star} \mathrm{p}<0.05$; ${ }^{\star \star} \mathrm{p}<0.02 ;{ }^{\star \star \star} \mathrm{p}<0.01$

Table 4 Effect of $H$ pylori CagA/cytotoxin positive and CagA/cytotoxin negative strains on IL-8 mRNA in KATO-3 cells following three hours of co-culture

\begin{tabular}{|c|c|c|c|c|c|}
\hline & \multirow[b]{2}{*}{ Cell only control } & \multicolumn{2}{|c|}{ CagA/cytotoxin positive strains } & \multicolumn{2}{|c|}{ CagA/cytotoxin negative strains } \\
\hline & & NCTC 11637 & $G 32$ & G50 & $G 25$ \\
\hline $\begin{array}{l}\mathrm{IL}-8: G 3 P D H \\
\text { PCR products }\end{array}$ & $0.19(0.02)$ & $0.60(0.09)^{\star \star \star}$ & $0 \cdot 74(0 \cdot 18)^{\star \star \star}$ & $0.22(0.04)$ & $0.30(0.06)$ \\
\hline
\end{tabular}

Results expressed as a ratio of IL-8 to G3PDH PCR products, values are mean (SEM), $n=5$.

Mann-Whitney U test: ${ }^{\star \star \star} \mathrm{p}<0.01$.

Using a semiquantitative PCR technique, the relative induction of IL-8 mRNA in KATO-3 cells was compared with expression of G3PDH mRNA. At three hours there was a significant increase $(p<0.01)$ in IL-8 PCR product in the KATO-3 cells following co-culture with the $\mathrm{CagA} /$ cytotoxic strains (NCTC 11637 and G32) relative to unstimulated cells (fig 2, table 4). In contrast, coculture with the $\mathrm{CagA} /$ cytotoxic negative strains (G25 and G50) resulted in no increase in IL-8 PCR product (fig 2, table 4).

\section{Discussion}

It is now clear that human gastric epithelial cells express IL-8 in vivo and IL-8 expression is increased in $H$ pylori gastritis. ${ }^{17}$ Studies with gastric epithelial cell lines have shown that epithelial derived IL-8 is not only immunologically active but also biologically active inducing neutrophil migration ${ }^{18}$ and activation. ${ }^{30}$ The gastric epithelium therefore has the potential for an active role in host mucosal defences. The present study clearly shows that $H$ pylori directly increases gastric epithelial cell IL-8 mRNA expression and IL-8 protein secretion in a strain specific manner. The strain specificity of this response has important implications for the pathogenesis of $H$ pylori related gastroduodenal disease.

The gastric epithelium represents the primary interface with $H$ pylori. In acute gastritis the initial histopathological response is neutrophilic $^{31}$ and rapid secretion of IL- 8 by the epithelium may represent a primary host defence mechanism. The epithelial IL-8 response to $H$ pylori observed in this study was restricted to gastric cell lines, suggesting a specific host-bacterial interaction related to the specificity of colonisation within the gastroduodenal tract. Neither of the two intestinal cell lines, which are capable of secreting high concentrations of IL-8, produced IL-8 in response to $H$ pylori. It will be interesting to examine the IL-8 responses of epithelial cells from non-gastrointestinal sites to $H$ pylori to investigate further the specificity of this response. Recent studies have shown that cervical $^{32}$ and bronchial ${ }^{33}$ epithelial cells will produce IL-8 in response to a range of bacterial species.

$H$ pylori induced stimulation of IL-8 from gastric epithelial cell lines was dependent on the presence of viable bacteria, with formalin fixation, heat killing, sonication, and freezethawing of organisms all substantially reducing their ability to stimulate IL-8. The dependence on live $H$ pylori bacteria suggests that induction of IL-8 requires an active process. Interestingly, recent studies on polymorph transepithelial migration in response to Salmonella typhimurium also showed that direct bacterial-epithelial contact and bacterial protein synthesis were essential. ${ }^{34}$

Recent studies on a range of enteric pathogenic bacteria suggest that IL-8 is secreted from intestinal cells in response to bacterial invasion. ${ }^{32}$ However, ultrastructural studies on the gastric epithelial cell lines used in this study have shown frequent internalisation of $H$ pylori into AGS and ST42 cell lines but minimal invasion of KATO-3 cells (unpublished data). IL-8 stimulation by $H$ pylori, whilst requiring viable organisms, is therefore unlikely to relate directly to internalisation, as similar strain specific patterns of IL-8 responses were observed in all three cell lines.

CagA/cytotoxic strains of $H$ pylori induced significantly higher degrees of epithelial IL-8 secretion and IL-8 mRNA expression than CagA/cytotoxic negative strains. Our previous studies have identified that mucosal immune recognition of the CagA protein is strongly associated with epithelial polymorph infiltration..$^{20}$ Increased stimulation of epithelial IL-8 induced by $\mathrm{CagA} /$ cytotoxic strains may be critical in inducing enhanced gastric neutrophil migration and activation. Once activated, neutrophils will also secrete IL-8, thus perpetuating the inflammatory response to infection ${ }^{35}$ and the potential for mucosal damage. The local production of IgA autoantibodies to IL-8, however, may represent a down-regulatory mechanism of the host to block excessive IL-8 induced neutrophil activation. ${ }^{8}$

There is now increasing evidence linking strains of $H$ pylori expressing the cytotoxin and associated CagA protein with gastroduodenal disease. Patients with peptic ulcers are 
more likely to be infected with strains of $H$ pylori which are cytotoxic. ${ }^{36}$ Increased mucosal $\operatorname{IgA}^{20}$ and systemic IgG ${ }^{21} 2237$ recognition of the cytotoxin-associated high molecular weight CagA protein is evident in patients with peptic ulcer disease. Patients with gastric cancer also show increased serological recognition of the CagA protein relative to subjects with non-ulcer dyspepsia. ${ }^{38}$

Whether the consistent association of $\mathrm{CagA} /$ cytotoxic $H$ pylori strains with gastroduodenal disease is a consequence of their cytotoxicity is unclear. Serum $\operatorname{IgG}^{39}$ and mucosal IgA ${ }^{40}$ antibodies inhibit cytotoxicity in vitro, suggesting that if a similar phenomenon occurs in vivo, the cytotoxin may not be the primary virulence factor inducing mucosal damage. In the present study monensin, an inhibitor of cytotoxicity in vitro, ${ }^{29}$ reduced $H$ pylori induced epithelial IL-8 secretion. However, this effect could not be attributed to blocking of a specific bacterial induction mechanism as IL-1 $\beta$ induced IL-8 secretion was similarly inhibited by monesin.

The monesin induced reduction in IL-8 secretion is presumably a consequence of impairment of Golgi function and intracellular transport. ${ }^{41}{ }^{42}$ Ultrastructural studies (unpublished observations) have also shown that at the bacteria:cell ratio used in our study, there was minimal evidence of intracytoplasmic vacuolisation at 24 hours in the three gastric cell lines. In contrast to the cytotoxin, the function of the CagA protein is unknown. This highly immunogenic protein is located on the surface but whether it is involved in epithelial cell adhesion is currently unclear.

Further studies using mutant strains of $H$ pylori should determine the relative roles of the CagA protein and the cytotoxin in the stimulation of gastric epithelial IL-8 production. Whilst epithelial expression of IL-8 will also be regulated by cytokines, ${ }^{18}$ with the local production of tumour necrosis factor $^{43}$ increasing expression, identification of specific $H$ pylori components inducing epithelial IL-8, and the gastric epithelial cell receptors involved, may facilitate the development of novel gastric anti-inflammatory agents. This study was undertaken with financial assistance of the
Yorkshire Regional Health Authority, Airedale Hospital Trust, Yorkshire Regional Health Authority, Airedale Hospital Trust,
and St James's Hospital Trust. We thank Dr M Ceska for purification of the IL-8 monoclonal antibody.

1 Dixon MF. Helicobacter pylori and peptic ulceration histopathological aspects. F Gastroenterol Hepatol 1991;6: 125-30.

2 Rautelin H, Blomberg B, Fredlund H, Jarnerot G, Danielsson D. Incidence of Helicobacter pylori strains activating neutrophils in patients with peptic ulcer activating neutrophils in patien

3 Weiss SJ. Tissue destruction by neutrophils. N Engl f Med 989;320:365-76.

4 Mai UEH, Perez-Perez GI, Allen JB, Wahl SM, Blaser MJ, Smith PD. Surface proteins from Helicobacter pylor exhibit chemotactic activity for human leukocytes and are present in gastric mucosa. $f$ Exp Med 1992 175:517-25.

5 Nielsen H, Andersen LP. Chemotactic activity of Helicobacter pylori sonicate for human polymorphonuclear leucocytes and monocytes. Gut 1992;33:738-42.

6 Craig PM, Territo MC, Karnes WE, Walsh JH. Helicobacter pylori secretes a chemotactic factor

7 Nielsen H, Andersen LP. Activation of human phagocytic oxidative metabolism by Helicobacter pylori. Gastro-
enterology 1992;103:1747-53.

8 Crabtree JE, Peichl P, Wyatt JI, Stachl U, Lindley IJD. Gastric interleukin-8 and IgA IL-8 autoantibodies in
Helicobacter pylori infection. Scand F Immunol 1993; 37:65-70.

9 Matsushima K, Morishita K, Yoshimura T, Lavu S, Kobayshi Y, Lew W, et al. Molecular cloning of human monocyte-derived neutrophil chemotactic factor (MDNCF) and induction of MDNCF by interleukin-1 and tumour necrosis factor. $f$ Exp Med 1988;167: 1883-93.

10 Lindley I, Aschauer H, Siefert JM, Lam C, Brunowsky W, Konatzki E, et al. Synthesis and expression in Escherichia coli of the gene encoding monocyte-derived neutrophil activating factor: biological equivalence between natural and recombinant neutrophil-activating between natural and recombinant neutrophil-activating
factor. Proc Natl Acad Sci USA 1988;85:9199-203.

11 Oppenheim JJ, Zachariae COC, Mukaiada N, Matsushima $\mathrm{K}$. Properties of the novel proinflammatory supergene intercrine cytokine family. Ann Rev Immunol 1991;9: 617-48.

12 Donnelly SC, Strieter RM, Kunkel SL, Walz A, Robertson $\mathrm{CR}$, Carter DC, et al. Interleukin-8 and adult respiratory distress syndrome in at-risk patient groups. Lancet 1993;341:643-7.

13 Peichl P, Ceska M, Effenberger F, Haberhauer G, Broell $\mathrm{H}$, Lindley IJD. Presence of NAP/IL-8 in synovial fluids indicates a possible pathogenic role in rheumatoid indicates a possible pathogenic role in

14 Mahida YR, Ceska M, Effenberger F, Kurlak L, Lindley I, Hawkey CJ. Enhanced synthesis of neutrophil-activating peptide-1/interleukin-8 in active ulcerative colitis. Clin Sci 1992;82:273-5.

15 Ho YC, Mukaida N, Ishiyama S, Tokue A, Kawai T, Matsushima K, et al. Elevated interleukin-8 levels in the urine of patients with urinary tract infections. Infect Immun 1993;61:1307-14.

16 Friedland JS, Suputtamongkol Y, Remick DG, Chaowagul W, Strieter RM, Kunkel SL, et al. Prolonged elevation of interleukin-8 and interleukin-6 Prolonged elevation of interleukin-8 and interleukin-6 concentrations in plasma and of leukocyte interleukin-8
mRNA levels during septicemic and localized Pseudomonas pseudomallei infection. Infect Immun 1992;60:2402-8

17 Crabtree JE, Wyatt JI, Trejdosiewicz LK, Peichl P, Nichols PN, Ramsay N, et al. Interleukin-8 expression in Helicobacter pylori infected, normal, and neoplastic gastroduodenal mucosa. F Clin Pathol 1994;47:61-6.

18 Yasumoto K, Okamoto S, Mukaida N, Murakami S, Mai $M$, Matsushima K. Tumour necrosis factor $\alpha$ and interferon [g19] synergistically induce interleukin 8 production in a human gastric cancer cell line through acting concurrently on AP-1 and NF-kB-like binding sites of the interleukin 8 gene. $\mathcal{f}$ Biol Chem 1992;267:22506-11.

19 Agace WW, Hedges SR, Ceska M, Svanborg C Interleukin-8 and the neutrophil response to mucosa gram-negative infection. $\mathcal{F}$ Clin Invest 1993;92:780-5.

20 Crabtree JE, Taylor JD, Wyatt J, Heatley RV, Shallcros TM, Tompkins DS, et al. Mucosal IgA recognition of Helicobacter pylori $120 \mathrm{kDa}$ protein, peptic ulceration and gastric pathology. Lancet 1991;338:332-5.

21 Figura N, Bugnoli M, Cusi MG, Pucci AM, Lusini P, Quaranta S, et al. Pathogenic mechanisms of Helicobacter pylori: production of cytotoxin. In: Malfertheiner P, Ditschneit H, eds. Helicobacter pylori, gastritis and pepP, Ditschneit H, eds. Helicobacter pylori, gastritis

22 Cover TL, Dooley CP, Blaser MJ. Characterization of and human serologic response to proteins in Helicobacter pylori broth culture supernatants with vacuolizing cytotoxin activity. Infect Immun 1990;58:603-10.

23 Crabtree JE, Figura N, Taylor JD, Bugnoli M, Armellini D, Tompkins DS. Expression of 120 kilodalton protein and cytotoxicity in Helicobacter pylori. $\mathcal{F}$ Clin Pathol 1992;45:733-4.

24 Covacci A, Censini S, Bugnoli M, Petracca R, Burroni D, Macchia G, et al. Molecular characterization of the 128$\mathrm{kDa}$ immunodominant antigen of Helicobacter pylori $\mathrm{kDa}$ immunodominant antigen of Helicobacter pylori Natl Acad Sci USA 1993;90:5791-5.

25 Tummura MKR, Cover TL, Blaser MJ. Cloning and expression of a high-molecular-mass major antigen of Helicobacter pylori: evidence of linkage to cytotoxin production. Infect Immun 1993;61:1799-809.

26 Hojo J. Establishment of cultured cell lines of human stomach cancer origin and their morphological characteristics. Niigata Igakukai Zasshi 1977;91:737-63.

27 Durrant LG, Watson SA, Hall A, Morris DL. Co-stimulation of gastrointestinal tumour cell growth by gastrin, transforming growth factor $\alpha$ and insulin like growth transforming growth factor $\alpha$ and

28 Eckmann L, Jung HC, Schurer-Maly C, Panja A Morzycka-Wroblewska E, Kagnoff MF.' Differential cytokine expression by human intestinal epithelial cell lines: regulated expression of interleukin-8. Gastroenterology 1993;105:1689-97.

29 Cover TL, Vaughn SG, Cao P, Blaser MJ. Potentiation of Helicobacter pylori vacuolating toxin activity by nicotine and other weak bases. $\mathcal{F}$ Infect Dis 1992;166:1073-8.

30 Plusa S, Farmery S, Peichl P, Lindley IJD, Primrose JN, Crabtree JE. Secretion of immunologically and biologically active interleukin- 8 by a gastric epithelial cell line. Gut 1993;34(suppl 4):S15.

31 Sobala GM, Crabtree JE, Dixon MF, Sehorah CJ, Taylor JD, Rathbone BJ, et al. Acute Helicobacter pylori infection: clinical features, local and systemic immune infection: clinical features, local and systemic immune response, gastric mucosal histology, and gastric
juice ascorbic acid concentrations. Gut 1991;32: juice ascor $1415-18$.

32 Eckmann L, Kagnoff MF, Fierer J. Epithelial cells secrete 
the chemokine interleukin- 8 in response to bacterial entry. Infect Immun 1993;61:4569-74.

33 Massion PP, Inoue H, Richman-Eisenstat J, Grunberger D, Jorens PG, Housset B, et al. Novel Pseudomanas product stimulates interleukin-8 production in airway epithelial cells in vitro. $\mathcal{F}$ Clin Invest 1994;93:26-32.

34 McCormick BA, Coglan SP, Delp-Archer C, Millir SI, Madara JL. Salmonella typhimurium attachment to intestinal epithelial monolayers: transcellular signalling intestinal epithelial monolayers: transcellular signalling to subep

35 Strieter RM, Kasahara K, Allen RM, Standiford TJ, Rolfe MW, Becker FS, et al. Cytokine-induced neutrophil derived interleukin-8. Am $\mathcal{F}$ Pathol 1992;141:397-407.

36 Figura N, Guglielmetti A, Rossolini A, Barberi A, Cusi G Musmanno RA, et al. Cytotoxin production by Campylobacter pylori strains isolated from patients with peptic ulcers and from patients with chronic gastritis only. $\mathcal{F}$ Clin Microbiol 1989;27:225-6.

37 Xiang Z, Bugnoli M, Rappuoli R, Covacci A, Ponzetto A Crabtree JE. Helicobacter pylori: host responses in peptic ulceration. Lancet 1993;341:900-01.
38 Crabtree JE, Wyatt JI, Sobala GM, Miller G, Tompkins DS, Primrose JN, et al. Systemic and mucosal humoral responses to Helicobacter pylori in gastric cancer. Gut 1993;34:1339-43.

39 Cover TL, Coa P, Murthy U, Sipple MS, Blaser MJ Serum neutralizing antibody response to the vacuolating cytotoxin of Helicobacter pylori. $\mathcal{F}$ Clin Invest 1992;90: 913-18.

40 Figura N, Crabtree JE. Vacuolating toxin of Helicobacter pylori. In: Hunt R, Tytgat G, eds. Helicobacter pylori: basic mechanisms to clinical cure. Amsterdam: Kluwe Academic Publishers, 1994:222-31.

41 Tartakoff AM. Perturbation of vesicular traffic with carboxylic ionophore monensin. Cell 1983;32:1026-8.

42 Mollenhauer HH, Morre DJ, Rowe LD. Alteration of intracellular traffic by monensin; mechanisms, specificity and relationship to toxicity. Biochim Biophys Acta 1990;1031:225-46.

43 Crabtree JE, Shallcross TM, Heatley RV, Wyatt II Mucosal tumour necrosis factor $\alpha$ and interleukin- 6 in patients with Helicobacter pylori associated gastritis. Gut patients with Helicot. 